\title{
A novel presenilin mutation (M233V) causing very early onset Alzheimer's disease with Lewy bodies
}

\author{
Henry Houlden ${ }^{a, b}$, Richard Crook ${ }^{a}$, R.J. Dolan ${ }^{c}$, Jim McLaughlin $^{d}$, \\ Tamas Revesz ${ }^{\mathrm{e}}$, John Hardy ${ }^{\mathrm{a}, *}$ \\ ${ }^{a}$ Department of Neuroscience, Mayo Clinic, Jacksonville, FL 32224, USA \\ ${ }^{b}$ Department of Clinical Neurology, Institute of Neurology, University College London, Queen Square London WC1N 3BG, UK \\ ${ }^{c}$ Department of Cognitive Neurology, Institute of Neurology, University College London, Queen Square London WC1N 3BG, UK \\ ${ }^{d}$ Department of Pathology, Royal Free Hospital, London, UK \\ ${ }^{e}$ Department of Neuropathology, Institute of Neurology, University College London, Queen Square London WC1N 3BG, UK
}

Received 15 May 2001; received in revised form 16 August 2001; accepted 16 August 2001

\begin{abstract}
Presenilin 1 mutations are the major cause of autosomal dominant Alzheimer's disease: here we identify a new missense mutation causing a methionine to valine change at codon 233. This codon is homologous to a pathogenic presenilin 2 mutation with the same base change (ATG to GTG) and amino acid change (M239V). This mutation causes disease with an exceptionally early onset age ( 30 years) in which pathological examination shows extensive Lewy bodies as well as plaques and tangles. (c) 2001 Elsevier Science Ireland Ltd. All rights reserved.
\end{abstract}

Keywords: Alzheimer's disease; Genetics; Presenilins; Lewy bodies

Presenilin 1 mutations are the major cause of early onset, autosomal dominant Alzheimer's disease [18]. Approximately 80 mutations have been described [3] and these are all believed to lead to disease through the alteration of amyloid precursor protein (APP) processing such that more of the amyloidogenic peptide $\mathrm{A} \beta 42$ is produced $[6,17]$. Pathogenic presenilin mutations are scattered throughout the molecule. There is a predilection for the exon 8 region [14] and for the transmembrane (TM) domains $[2,11]$.

A family with exceptionally early onset of Alzheimer's disease inherited as an autosomal dominant trait (Fig. 1) came to our attention. In this family, the presenting features have been between 28 and 34 years and the age at death has been between 34 and 37 years. The proband died at age 34, after an extremely rapid course involving predominantly extrapyramidal features and early seizures. The pathology of her case has previously been described as including high counts of neurofibrillary tangles and amyloid plaques throughout the cerebral neocortical areas examined including occasional plaques in the spinal cord. There was occa-

\footnotetext{
* Corresponding author. Tel.: +1-904-9537-356; fax: +1-904953-7370.

E-mail address: hardy@mayo.edu (J. Hardy).
}

sional diffuse amyloid plaques in the striatum with dense plaques and occasional neurofibrillary tangles being present in both the external and internal segments of the pallidum. There were many nigral and cortical Lewy bodies [15] (Fig. 2 ) and the presence of moderate to severe amyloid angiopathy in leptomeningeal, cerebral and cerebellar vessels.

DNA was extracted from blood and brain tissue. DNA sequencing of the proband, carried out as we have previously described [2] revealed an ATG to GTG mutation at codon 233 leading to a predicted methionine to valine change at this residue of PS 1 exon 7. This caused the loss of a Nla III restriction enzyme cut in the mutant allele. No other relatives were available in the family. This mutation was not present in 150 control chromosomes.

This finding is of interest for three reasons: first, and simply, as a documentation of a new mutation. This codon is homologous to a pathogenic presenilin 2 mutation with the same bases change (ATG to GTG) and amino acid change (M239V) [16]. Second; this mutation occurs to the same residue as two previous mutations, M233L and M233T. These mutations are in predicted TM domain 5 [1,9]. While mutations to this domain do not align along predicted helical faces [5], it is clear that mutations do cluster to particular residues in both presenilin 1 and 2 . The other two reported mutations at codon 233 cause an age of 


\section{Family}

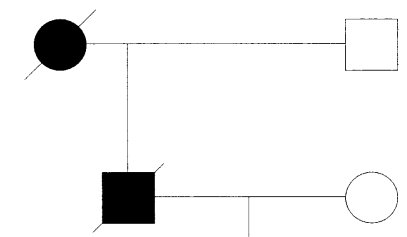

Died 37, AD

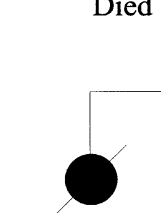

Died 37, AD

Died 36, AD

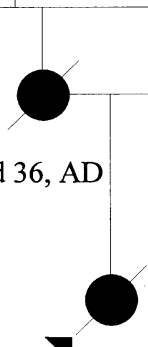

Filled symbols $=$ Alzheimer's disease

Onset 28, died 34, AD

Fig. 1. The family tree: the mean age at onset of the family is 32 years (range 30-34). This pedigree and the pathology of the proband has been previously described in reference [15] as Pedigree 2.

onset of 46 years in one family (M233L) and in the other a very early age of onset of 35 years (M233T) with early seizures. In this TM domain there is no significant trend in age of onset, clinical or pathological features $[3,8,12,13]$. Third, the occurrence of Lewy bodies in this case confirm our and others' previous observations in cases with both APP and presenilin mutations that Lewy bodies are a significant pathological feature $[4,6-$ $8,10,12,13]$. No detailed neuropathological details were available on the two other families with mutations at this residue to compare with our case. Lewy bodies have been identified in a number of different families with presenilin mutations in different TM domains but so far no correlations can be identified to link mutation position with neuropathology.

These data suggests that Lewy body formation is likely to be a downstream event from APP misprocessing [4-8] although the mechanism of their formation is as yet unknown. The occurrence of Lewy bodies in the brains of one so young can clearly not be an event unrelated to the pathological processes deriving from the presenilin mutation.

This work was supported by an NIH/NIA program project grant to J.H. and by the Mayo Foundation. Collaborations between the Mayo Neurogenetics Labs and National Hospital for Neurology and Neurosurgery have been supported by the Wellcome Trust (H.H.) and the Bogue Fellowship (H.H.). For an updated view of presenilin mutations, see the databases at www.alzforum.org and http://molgenwww.uia.ac.be/ADMutations/
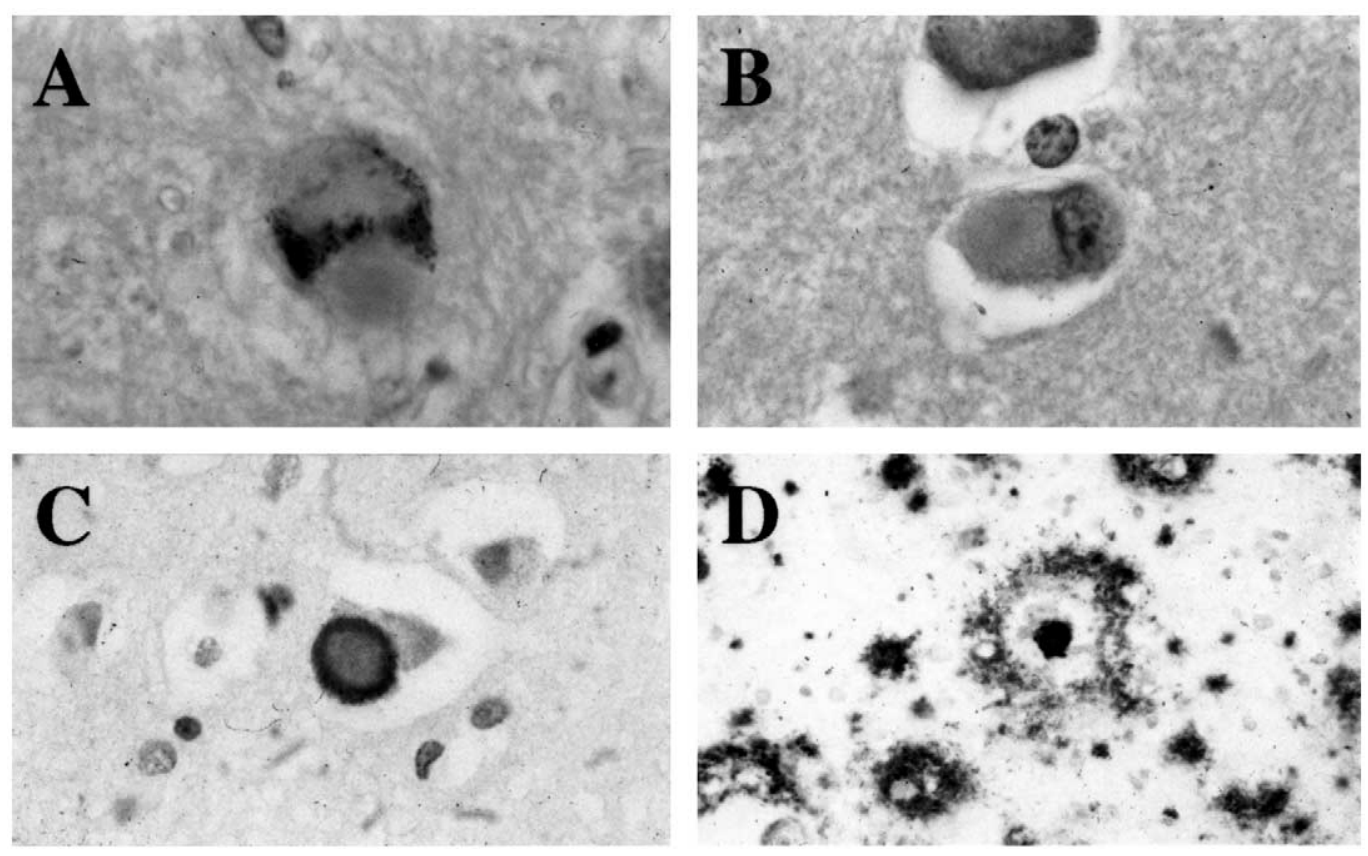

Fig. 2. (A) Nigral neuron with typical Lewy body. (B) Cortical Lewy body in the cingulum cortex. (C) Cortical Lewy body stained with an antibody to $\alpha$-synuclein. (D) Numerous neocortical A $\beta$-positive senile plaques. (A and B: Haematoxylin and eosin, original magnification $\times 300$; $\mathrm{C}: \alpha$-synuclein immunohistochemistry original magnification $\times 300 ; \mathrm{D}: \mathrm{A} \beta$ immunohistochemistry original magnification $\times$ 90). 
[1] Aldudo, J., Bullido, M.J. and Valdivieso, F., DGGE method for the mutational analysis of the coding and proximal promoter regions of the Alzheimer's disease presenilin-1 gene: two novel mutations, Hum. Mutat., 14 (5) (1999) 433-439.

[2] Clark, R.F., Hutton, M., Fuldner, R.A., Froelich, S., Karran, E., Talbot, C., Crook, R., Lendon, C., Prihar, G., He, C., Korenblat, K., Martinez, A., Wragg, M., Busfield, F., Behrens, M.I., Myers, A., Norton, J., Morris, J., Mehta, N., Pearson, C., Lincoln, S., Baker, M., Duff, K., Zehr, C., Pereztur, J., Houlden, H., Ruiz, A., Ossa, J., Lopera, F., Arcos, M., Madrigal, L., Collinge, J., Humpreys, C., Ashworth, A., Sarner, S., Fox, N., Harvey, R., Kennedy, A., Roques, P., Cline, R.T., Phillips, C.A., Venter, J.C., Forsell, L., Axelman, K., Lilius, L., Johnston, J., Cowburn, R., Vitanen, M., Winblad, B., Kosik, K., Haltia, M., Poyhonen, M., Dickson, D., Mann, D., Neary, D., Snowden, J., Lantos, P., Lannfelt, L., Rossor, M., Roberts, G.W., Adams, M.D., Hardy, J. and Goate, A., The structure of the presenilin 1 (S182) gene and identification of six novel mutations in early onset $A D$ families, Nat. Genet., 11 (1995) 219-222.

[3] Cruts, M. and Van Broeckhoven, C., Molecular genetics of Alzheimer's disease, Ann. Med., 30 (1998) 560-565.

[4] Hansen, L.A., Masliah, E., Galasko, D. and Terry, R.D., Plaque-only Alzheimer disease is usually the lewy body variant, and vice versa, J. Neuropathol. Exp. Neurol., 52 (6) (1993) 648-654.

[5] Hardy, J. and Crook, R., Presenilin mutations align along faces of predicted transmembrane domains, Neurosci. Lett., 306 (3) (2001) 203-205.

[6] Hardy, J., Amyloid, the presenilins and Alzheimer's disease, Trends Neurosci., 20 (1997) 154-159.

[7] Hardy, J., Pathways to primary neurodegenerative disease, Mayo Clinic Proc., 74 (1999) 835-837.

[8] Ishii, K., Lippa, C., Tomiyama, T., Miyatake, F., Ozawa, K., Tamaoka, A., Hasegawa, T., Fraser, P.E., Shoji, S., Nee, L.E., Pollen, D.A., St George-Hyslop, P.H., Li, K., Ohtake, T., Kalaria, R.N., Rosser, M.N., Lantos, P.L., Cairns, N.J., Farrer, L.A. and Mori, H., Distinguishable effects of Presenilin-1 and APP717 mutations on amyloid plaque deposition, Neurobiol. Aging, 22 (2001) 367-376.

[9] Kwok, J.B., Taddei, K., Hallupp, M., Fisher, C., Brooks, W.S., Broe, G.A., Hardy, J., Fulham, M.J., Nicholson, G.A., Stell, R., St George Hyslop, P.H., Fraser, P.E., Kakulas, B., Clarnette, R., Relkin, N., Gandy, S.E., Schofield, P.R. and Martins, R.N., Two novel (M233T and R278T) presenilin-1 mutations in early-onset Alzheimer's disease pedigrees and preliminary evidence for association of presenilin-1 mutations with a novel phenotype, NeuroReport, 8 (6) (1997) 1537-1542.

[10] Lantos, P.L., Ovenstone, I.M., Johnson, J., Clelland, C.A., Roques, P. and Rossor, M.N., Lewy bodies in the brain of two members of a family with the 717 (Val to lle) mutation of the amyloid precursor protein gene, Neurosci. Lett., 172 (1-2) (1994) 77-79.
[11] Li, X. and Greenwald, I., Additional evidence for an eighttransmembrane-domain topology for Caenorhabditis elegans and human presenilins, Proc. Natl. Acad. Sci. USA., 95 (1998) 7109-7114.

[12] Lippa, C.F., Fujiwara, H., Mann, D.M., Giasson, B., Baba, M., Schmidt, M.L., Nee, L.E., O'Connell, B., Pollen, D.A., St George-Hyslop, P., Ghetti, B., Nochlin, D., Bird, T.D., Cairns, N.J., Lee, V.M., Iwatsubo, T. and Trojanowski, J.Q., Lewy bodies contain altered alpha-synuclein in brains of many familial Alzheimer's disease patients with mutations in presenilin and amyloid precursor protein genes, Am. J. Pathol., 153 (5) (1998) 1365-1370.

[13] Mann, D.M., Pickering-Brown, S.M., Takeuchi, A. and Takeshi Iwatsubo, T., and the members of the Familial Alzheimer's Disease Pathology Study Group. Amyloid angiopathy and variability in amyloid beta deposition is determined by mutation position in presenilin-1-linked Alzheimer's disease, Am. J. Pathol., 158 (6) (2001) 21652175.

[14] Perez-Tur, J., Croxton, R., Wright, K., Phillips, H., Zehr, C., Crook, R., Hutton, M., Hardy, J., Karran, E., Roberts, G.W., Lancaster, S. and Haltia, T., A further presenilin 1 mutation in the exon 8 cluster in familial Alzheimer's disease, Neurodegeneration, 5 (1996) 207-212.

[15] Revesz, T., McLaughlin, J.L., Rossor, M.N. and Lantos, P.L., Pathology of familial Alzheimer's disease with Lewy bodies, J. Neurol. Transm., 51 (1997) 121-135.

[16] Rogaev, E.I., Sherrington, R., Rogaeva, E.A., Levesque, G., Ikeda, M., Liang, Y., Chi, H., Lin, C., Holman, K., Tsuda, T., Mar, L., Sorbi, S., Nacmias, B., Piacentini, S., Amaducci, L., Chumakov, I., Cohen, D., Lannfelt, L., Fraser, P.E., Rommens, J.M. and St George-Hyslop, P.H., Familial Alzheimer's disease in kindreds with missense mutations in a gene on chromosome 1 related to the Alzheimer's disease type 3 gene, Nature, 376 (6543) (1995) 775-778.

[17] Scheuner, D., Eckman, C., Jensen, M., Song, X., Citron, M., Suzuki, N., Bird, T.D., Hardy, J., Hutton, M., Kukull, W., Larson, E., Levey-Lahad, E., Viitanen, M., Peskind, E., Poorkaj, P., Schellenberg, G., Tanzi, R., Wasco, W., Lannfelt, L., Selkoe, D. and Younkin, S., Secreted amyloid $\beta$-protein similar to that in the senile plaques of Alzheimer's disease is increased in vivo by the presenilin 1 and 2 and APP mutations linked to familial Alzheimer's disease, Nat. Med., 2 (1996) 864-870.

[18] Sherrington, R., Rogaev, E.I., Liang, Y., Rogaeva, E.A., Levesque, G., Ikeda, M., Chi, H., Lin, C., Li, G., Holman, K., Tsuda, T., Mar, L., Foncin, J.F., Bruni, A.C., Montesi, M.P., Sorbi, S., Rainero, I., Pinessi, L., Nee, L., Chumakov, I., Pollen, D., Brookes, A., Sanseau, P., Polinsky, R.J., Wasco, W., Dasilva, H.A.R., Haines, J.L., Pericakvance, M.A., Tanzi, R.E, Roses, A.D., Fraser, P.E., Rommens, J.M. and St George-Hyslop, P.H., Cloning of a gene bearing missense mutations in early-onset familial Alzheimer's disease, Nature, 375 (1995) 754-760. 